VISION: Journal of Indian Taxation Volume 4, Issue 1, January-June 2017, pp. 51-67 doi: 10.17492/vision.v4i01.9993

\title{
GST and the Paradigm Shift: A Peripheral View
}

\author{
Priyakrushna Mohanty* and Anu Chandran**
}

\begin{abstract}
The Goods and Services Tax (GST) has been touted as the single biggest tax reform in the Republic of India. The GST Act proposes to replace all the indirect taxes with a single GST. The profound positive impact of the Act has been reflected in many works in literature. However, the Act has also been criticised for its complex and retrospective nature. The current academic papers on GST are mainly focused on the brighter side of it and very few of them have provided an all-encompassing picture of the Act. In this backdrop, the present article attempts to highlight the benefits and concerns related to this Act by taking cues mainly from the write-ups published in the newspapers as well as academic works.
\end{abstract}

Keywords: Goods and Service Tax; GDP; Indirect taxes; Economic Growth.

\subsection{Introduction}

The first mention about GST dates back to 2000 when the then Prime Minister of India, Shri Atal Bihari Vajpayee set up an Empowered committee to draft a review on GST (Teltumbde, 2017) under the headship of Asim Dasgupta, the then Finance Minister of West Bengal.(ET Bureau, 2016; Gupta, 2017). Since then GST has moved though different phases of consideration, modification and ratification spanning over a period of 17 years before getting launched at the stroke of midnight hour on $30^{\text {th }}$ June- $1^{\text {st }} \mathrm{July}$, 2017 by the President of India under the name of The Constitution (One Hundred and First Amendment) Act, 2016. Promoted under the flagship of 'One Nation, One Tax' the historic move has been touted as the single biggest tax reform since the independence of India and has been symbolically considered as synonymous to the movement of political unification carried out by Sardar Vallabhbhai Patel during 1947-48 (Teltumbde, 2017).

*Corresponding author; Research Scholar, Department of Tourism Studies, Pondicherry University, Puducherry, India. (Email id: pkmohanty90@gmail.com)

**Assistant Professor, Department of Tourism Studies, Pondicherry University, Puducherry, India.(Email id: anoos_ind@yahoo.co.in) 
At the very rudimentary level, GST can be defined as an all-inclusive, multistage, destination based tax that is going to be levied on the value additions made by different channel intermediaries at each step in the production-selling process. The logic behind calling it an all-inclusive tax is because of the very fact that GST has replaced all the indirect taxes that were previously levied on goods and services. Further, it is a multi-stage tax as it will be levied at each stage in the production-selling process wherever any value additions are made. Last but not the least, it is a destination based tax which implies it tries to underscore that taxes will be levied on all the intermediaries in the manufacturing process

The tax structure in the pre-GST period consisted of a number of indirect taxes making it complex and riddling. By definition, GST is a comprehensive and unified indirect tax (more specifically a Value Added Tax) that is levied on the supply of goods and services (not on the manufacturing or sales or on provision of services) inside the Indian Territory. Hence, GST has been recognised as a move that simplifies the indirect tax structure in India (Lourdunathan and Xavier, 2017). GST has also been regarded at a higher pedestal as it will reduce the cascading effect of tax or double taxation by providing the input tax credit. Overall, this will reduce the tax burden on the consumer and if implemented properly prices may also see significant reduction (Vasanthagopal, 2011).

However, since the very conception of the dual GST system there has been notable number of studies that has criticised the Bill and evinced concerns over its structure, functions and implementation (Datar and Vaitheeswaran, 2015). One of the major criticisms that GST is facing today is the fact that the structure of GST in most of the developed countries is of single GST system whereas India has implemented a dual GST system. The arguments in support of dual GST are backed by the logic that in a federal structure like India, dual GST is the most appropriate mechanism. Yet, given the implementation of dual GST system, India is having 37 taxing statutes (1 central, 29 States and 7 UTs), which is contradicting with the concept of 'One Nation, One Tax' (Mukhopadhyay and Poddar, 2009). Further, there are almost 7 tax rates (0\%, 0.25\%, $3 \%, 5 \%, 12 \% .18 \%$ and $28 \%$,) excluding the taxes on consumption of sinful goods like tobacco, pan masala etc. that have supposedly made GST as complex as the previous taxation system. India is diverse a country and each state differs from the other in terms of polity, demography, economy, values etc. In this backdrop, implementing a unified GST system remains a biggest challenge for the ruling Government.

Thus, it could be seen that GST has both brighter as well as darker side that needs to be understood in order to depict all-encompassing picture of the Bill. Most of the information on GST is retrieved from the national dailies, which is scattered in 
nature. Therefore, this work has attempted to fill the gap by doing an extensive review of the write-ups and academic publications. It is inferred that GST is a very dynamic and broad area. While the long-term implications of GST have been tentatively forecast as given the Indian context, the efficacy of the same depends on a lot of extrinsic factors as well such as good governance, political will power, doing away with the red tapism, confidence building amongst citizens etc.

\subsection{Objectives of the paper}

Three objectives have been propounded for this study. The primary objective of this paper is to provide a simplified view of the GST regime and introduce the key terms and concepts associated with it. Secondly, the work also tries to provide a glance of GST history and major milestones achieved. Finally, the paper reflects the views of the various scholars and academicians with respect to GST that are necessary to be understood and analysed for developing a deeper understanding of the GST Bill and its implications.

\subsection{Research Methodology}

This paper has been crafted in an exploratory mode turning the spot light towards addressing, speculating and forecasting various probable impacts of GST. A comprehensive gamut of write-ups and columns has been reviewed to elicit pertinent information with respect to the Bill. Further, articles published in the academic journals (which are scarce) were collected and reviewed in order to set the background of the paper. Content analysis method was adopted to bring out the logical sequencing of the materials gathered, to avoid over reporting and problem of repetition and to enhance lucidity. Focused group discussion was carried out configuring academicians, experts and industry personnel as its members. The minutes of the discussion were then drawn out and inferences were featured in this paper. The data required for this paper have been collected from mostly secondary sources. The presentation of the paper is descriptive in nature. Data were also collected from the books, periodicals, official records, press releases and centre and state gazettes. Though majority of the concepts explained are qualitative in nature, some of the concepts involved quantitative analysis also.

\subsection{GST: An Overview}

As per the document titled 'GST: Concept and Status' issued by GST Council of India (as on May 1, 2017), GST can be defined as a comprehensive indirect tax which is based on the principle of destination based consumption tax (Behrensy et. al. 2004) that 
would replace the indirect taxes in the pre-GST era and would be levied on the supply of goods. The indirect taxes that GST is going to replace have been depicted in Figure 1. There would be a dual GST system with centre levying Central GST (CGST) and States (including Union Territories with Legislature) levying State GST (SGST). The Union Territories that do not have the Legislature will follow Union Territory legislature (UTGST). Beside CGST, SGST and UGST there would be another Integrated GST (IGST) that would be levied on the inter-state supply transactions (including stock transfers) and import of goods and services. Centre will be incharge of collection of IGST (GST Council of India, 2017a).

Figure 1: Components of GST

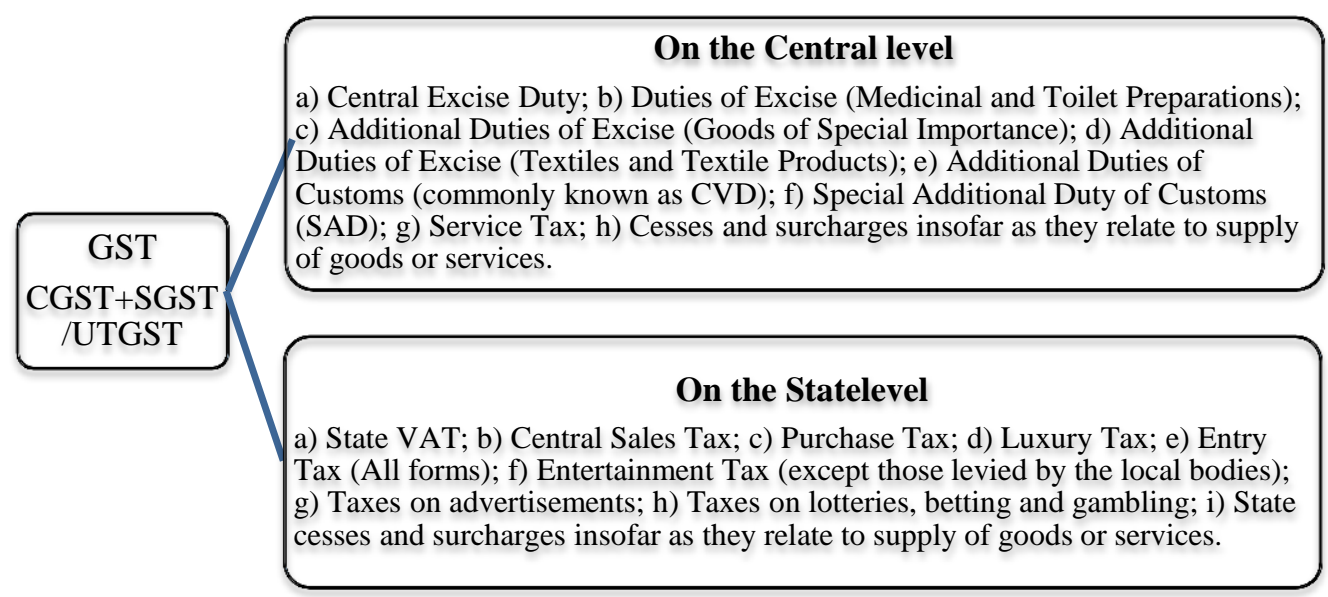

Source: - GST council document "GST - Concept and Status - As on 01st May, 2017a

There are mainly four tax rates of $5 \%, 12 \%, 18 \%$ and $28 \%$ that will be levied on all goods and services depending on the nature of the goods. Essential goods have been kept under the bracket of 5\% and $12 \%$ whereas non-essential goods and services have been kept under the bracket of $18 \%$. Luxury goods and services have been levied a maximum GST rate of $28 \%$. In addition, precious metals have been kept under the special GST rate of 3\% for gold and $0.25 \%$ for rough diamond (Jha, 2017). Goods and services which are very basic necessities have been exempted from GST. Alcohol for the purpose of consumption, 5 petroleum products (crude oil, petrol, HSD, ATF and natural gas), electricity charges and sale and purchase of real estate do not fall under the category of GST and continue to attract VAT and excise duty as before. Moreover, a 
cess over the GST rate of $28 \%$ will be levied on the sin goods like tobacco and pan masala (GST Council of India, 2017b). Further, GST follows a multi-stage collection mechanism which implies GST is levied at each stage of the supply chain starting from the manufacturer to the end consumer. However, if one has paid some amount of tax in the previous stage, he/she can avail the same amount as Input Tax Credit (ITC). Simply put, only value additions will be charged and will be borne by the consumer (GST Council of India, 2017b). The ITC is the credit that one supplier can avail in lieu of the tax already paid for incurring the inputs for manufacturing a product. ITC has been the underpinning aspect of GST as it will reduce the cascading effect of taxes i.e. tax on tax (Purohit, 1993) and reduce the overall burden of taxes on the consumer.

All firms having annual turnover over 20 lakhs will be levied GST except for North Eastern States where the annual turnover threshold is kept at 10 lakhs. In the preGST period, the threshold for paying VAT was set at 5 lakhs for goods and 10 lakhs for service providers. Hence, less number of firms will have to pay GST providing a sigh of relief to small retailers. However, retailers carrying out inter-state supply of goods and services have to register with GST mandatorily irrespective of their annual turnover. Also, for manufacturers the threshold exemption limit would be 20lakhs/annum which comes as a bad news for small manufacturers as their threshold exemption during the excise duty period was as high as 1.5 crores/annum.

There were speculations that manufacturing States may suffer losses due to GST and so there were lot of hue and cry as regards to unifying GST in the manufacturing States like Maharashtra or Tamil Nadu (Narasimhan, 2016). Keeping in mind the above mentioned argument, one more law called The Goods and Services Tax (Compensation to States) Act, 2017 was passed in the parliament. According to this law, compensation will be provided to those States who suffer losses in revenue due to GST implementation. The time period calculating the loss is set at 5 years from the first date of GST implementation (The Goods and Services Tax (Compensation to States) Act, 2017).To ensure Centre - State harmony and to establish single administrative control, it has been decided that the administrative control of $90 \%$ of the tax payers having annual turnover less than 1.5 crores will be vested with the State tax administration and rest $10 \%$ would remain in the hands of Central tax administration. Consequently, the administrative power of firms with turnover more than 1.5 crores will be divided equally i.e. $50 \%$ to Centre and $50 \%$ to States.

\subsection{Timeline of GST in India}

The concept of GST (alternatively called as VAT in most of the countries) was 
first conceptualised by a German business man Wilhelm Von Siemens who proposed to levy a destination based tax on the consumption of goods and services in the year 1919 (Bardopoulos, 2015). On a macro level, France was the first country to advocate VAT in 1954 under the aegis of Maurice Laure (Ecker, 2013). This 'new taxing system' was considered to be more effective as it reduced the cascading tax burden on consumers and Henceforth USA, Japan, the UK, South Korea and Japan adopted this taxing policy (Schenk and Oldman, 2001). Today, GST is a global phenomenon with over 150 countries practicing it and more than 100 countries having implemented GST in the last two decades. However, it must be noted that the structure of GST may vary from nation to nation as there are over 40 models of GST currently practiced all over the world (Teltumbde, 2017). It took almost 17 years for India to implement GST. There was a fair degree of agreements and oppositions before the Bill got launched on $1^{\text {st }} \mathrm{July}, 2017$. The timeline for GST in India has been depicted below in Table 1.

Table 1: Timeline of GST in India

\begin{tabular}{|c|c|c|}
\hline S.No. & Period & Details of the Advancements \\
\hline 1 & 2000 & $\begin{array}{l}\text { The then PM AB Vajpayee moots the idea of GST by setting up } \\
\text { an empowered committee under the headship of AsimDasgupta. }\end{array}$ \\
\hline 2 & 2003 & $\begin{array}{l}\text { The KelkarTsak force advances the idea of GST with suggestions } \\
\text { as FRBM (fiscal responsibility and budget management) } \\
\text { framework }\end{array}$ \\
\hline 3 & 28th Feb, 2006 & $\begin{array}{l}\text { The then FM P Chidambaram formally introduces the GST Bill } \\
\text { while presenting his budget speech with April 1, } 2010 \text { as its } \\
\text { deadline for roll out. }\end{array}$ \\
\hline 4 & $28^{\text {th }} \mathrm{Feb}, 2007$ & $\begin{array}{l}\text { Chidambaram reemphasizes on GST Bill and States that finance } \\
\text { ministers of States have agreed upon the idea of working with the } \\
\text { central Govt. to bring out a roadmap for GST. }\end{array}$ \\
\hline 5 & $10^{\text {th }}$ May, 2007 & $\begin{array}{l}\text { The Empowered committee of state finance ministers proposes to } \\
\text { set up a joint working group to draft a report on the probable } \\
\text { impacts of GST on the revenue of different States and feasibility } \\
\text { of implementation. }\end{array}$ \\
\hline 6 & $30^{\text {th }}$ Apr, 2008 & $\begin{array}{l}\text { Kelkar panel submits a draft titled "A Model and Roadmap for } \\
\text { GST in India" }\end{array}$ \\
\hline 7 & $10^{\text {th }}$ Nov, 2009 & $\begin{array}{l}\text { The detailed report on GST is submitted by the empowered } \\
\text { committee. }\end{array}$ \\
\hline 8 & $29^{\text {th }}$ Dec, 2009 & $\begin{array}{l}13^{\text {th }} \text { Finance Commission headed by Kelkar makes additional } \\
\text { suggestions with regards to GST formulation. }\end{array}$ \\
\hline
\end{tabular}




\begin{tabular}{|c|c|c|}
\hline 9 & $26^{\text {th }}$ Feb, 2010 & $\begin{array}{l}\text { The then FM Pranab Mukherjee announces the postponement of } \\
\text { the GST roll out to April, } 2010 \text {. }\end{array}$ \\
\hline 10 & $29^{\text {th }}$ Mar, 2011 & $\begin{array}{l}\text { The Constitution (115th Amendment) Bill was introduced I Lok } \\
\text { Sabha and GST Bill referred to Yashwant Singh headed standing } \\
\text { committee on finance. }\end{array}$ \\
\hline 11 & $7^{\text {th }}$ Aug, 2013 & $\begin{array}{l}\text { The standing committee submits the report in the Parliament. But } \\
\text { the Bill gets lapsed with the dissolution of } 15^{\text {th }} \text { LokSabha. }\end{array}$ \\
\hline 12 & June, 2014 & $\begin{array}{l}\text { Constitution Amendment Bill was sent to the empowered } \\
\text { committee following the approval from newly formed Modi } \\
\text { Government. }\end{array}$ \\
\hline 13 & $18^{\text {th }}$ Dec, 2014 & Cabinet approves the Constitution $\left(122^{\text {nd }}\right.$ Amendment) Bill \\
\hline 14 & $19^{\text {th }}$ Dec. 2014 & $\begin{array}{l}\text { The Constitution (122 } 2^{\text {nd }} \text { Amendment) Bill is introduced in Lok } \\
\text { Sabha. }\end{array}$ \\
\hline 15 & $6^{\text {th }}$ May, 2015 & Bill gets passed in Lok Sabha. \\
\hline 16 & $12^{\text {th }}$ May, 2015 & Bill introduced in the Rajya Sabha. \\
\hline 17 & $14^{\text {th }}$ May, 2015 & The Bill is submitted to the select committee of LS and RS. \\
\hline 18 & $22^{\text {nd }}$ July, 2015 & Select committee submits a report on GST. \\
\hline 19 & $1^{\text {st }}$ Aug, 2016 & $\begin{array}{l}\text { FM Arun Jaitley moves the amendments to Bill backed by the } \\
\text { political consensus. }\end{array}$ \\
\hline 20 & $3^{\text {rd }}$ Aug, 2016 & $\begin{array}{l}\text { The Constitution (122 } 2^{\text {nd }} \text { Amendment) Bill gets passed in Rajya } \\
\text { Sabha. }\end{array}$ \\
\hline 21 & $22^{\text {nd }}$ Sep, 2017 & GST council (Governing body of GST) was formed. \\
\hline 22 & $23^{\text {rd }}$ Sep, 2017 & $\begin{array}{l}\text { GST Network (GSTN), an online network to solve GST related } \\
\text { problems and queries was formed. }\end{array}$ \\
\hline 23 & $20^{\text {th }}$ Mar, 2017 & $\begin{array}{l}\text { PM Modi chaired cabinet approves four GST Bills namely CGST, } \\
\text { SGST, UTGST and IGST. }\end{array}$ \\
\hline 24 & $20^{\text {th }}$ May, 2017 & GST councils sets four GST rates rule $(5 \%, 12 \%, 18 \%$ and $28 \%)$ \\
\hline 25 & $20^{\text {th }}$ June, 2017 & $\begin{array}{l}\text { FM Jaitley announces the launch of GST on the lines of midnight } \\
\text { independence, on the midnight of } 30^{\text {th }} \text { June, } 2017\end{array}$ \\
\hline 26 & $1^{\text {st }}$ July, 2017 & $\begin{array}{l}\text { India enters the GST era on the stroke of midnight hour of } 30^{\text {th }} \\
\text { June. }\end{array}$ \\
\hline
\end{tabular}

Sources: Ministry of Finance, Government of India (2016); Ministry of Finance, Government of India (2017); ET Bureau (2016); Website of the GST Council; Gupta, (2017)

\subsection{Advocacies of GST: Reportage}

\subsection{Simplified tax system}

The most persistent argument made in favour of GST is that it will replace all the indirect taxes paid in the pre-GST period resulting in simplified tax system. GST will 
be a unified tax levied all across India on the supply of goods and services. There would be no distinction of taxes between goods and services. Further, exemption categories will be reduced and fewer rates will be implemented. Consumers will be more informed and empowered because of the simplicity in the tax structure.

\subsection{Lower Inflation}

It is believed that with the current GST in place, the inflation rates are expected to come down. Most of the basic food items and daily usage products have been kept in lower category which will result in lower CPI index (Dhanorkar, 2017). Further, it is argued that in the GST regime the cascading effect of taxes will be reduced to a greater extent which will reduce the overall tax burden on the consumer and with lessen tax burden as the price of the articles are expected to go down (Keshap, 2015).

\subsection{A move towards transparency and reduced corruption}

One of the most valued aspects of GST is the Input Tax Credit (ITC). The advocates of GST provides the logic that in the post GST period, suppliers will be entitled to claim the taxes that have been paid for incurring the inputs against the purchase invoices. Henceforth, there will be substantial reduction in the without Bill transaction i.e. tax evasion. Also, it would create a self-regulating tax system since every supplier will ask for the Bill that he/she will use for claiming the ITC.

To support the GST return (GSTR) process (that will be carried over online only), a GST Network (GSTN) has been designed by the GST council. Under this GSTN, the details of all the suppliers of goods and services will be uploaded. There is a provision for ranking the suppliers against their fair tax payment practices and other suppliers will have access to see the ranking and choose a fair dealer for trade. Hence, GST will be a move towards making the tax system transparent and corruption free.

\subsection{Perks for the poorer states}

As discussed earlier, GST is a destination based tax and hence the consuming States will be earning greater taxes. Most of the poorer Indian States like UP, Bihar, Madhya Pradesh are less industrialised. Owing to this, they consume more than they produce. With GST in place, these States will get their share of SGST. Secondly, due to the lower tax brackets the price of necessary goods will reduce which will be a sigh of relief for those States. Finally, in the GST regime the poorer States will not have to bear the burden of Central Sales Tax (CST) which was previously imposed on import of goods from producing States in the non-GST period. 


\subsection{Common market place}

Due to GST, there will be no differentiated VAT as per place of selling. In the pre-GST period the VAT system varied from state to state. So, there was set back if one wants sell goods in the higher VAT imposing States. The GST council is in a view that as GST is a single tax imposed pan India and hence there will be no loss or gain with respect to the place of selling. GST will make whole of India a common market place.

\subsection{Reward for small business units}

Under GST, business having turnover below Rs. 20 lakhs per annum (Rs. 10 lakhs per annum for special category States) has been exempted from paying GST. The preceding threshold in the pre-GST period was set at Rs. 10 lakhs per annum (Rs. 5 lakhs per annum for special category States). This means smaller business traders will enjoy the benefit of not paying GST and prosper further.

\subsection{Easy movement of goods}

GST has also replaced the entry tax that was paid at the border of different States when goods of one state enter into another state. Because of this entry tax, there were hundreds of lorries waiting in queues for getting the entry pass. Now, with GST most of the States have removed their boarder check posts facilitating easy movement of goods across States.

\subsection{Facilitating 'Make in India'}

'Make in India' was one of the landmark moves of the Modi Government to attract both foreign and domestic companies to set up their manufacturing units inside the Indian Territory. The current GST system is expected to facilitate the 'Make in India' movement in two ways. Firstly, exports of products and services from India will be zero rated i.e. products manufactured in India and exported to foreign market will be taxable under GST, but the rate of tax will be zero percent on their input supplies. As a result of this, more number of exporting units will be set up in India which can boost the employment opportunities. Secondly, in the pre-GST era, the imported produces were taxed with Special Additional Duties (SAD) only which was less than excise duty and VAT combined together. As a result, imported products were sold at a lesser rate because of lower tax burden and it was a huge setback for the domestic manufacturers. In the post-GST era, imports from foreign territories will be taxed with IGST which is equal to CGST and SGST combined together. Hence, domestic manufacturers will be protected and will enjoy competitive advantage of reduced transportation cost. 


\subsection{Challenges faced in enabling GST}

Even though the system of GST has been implemented in many other countries, Indian GST varies in many aspects from other GST models. Further, India is the largest democracy in the world and the diversity that India upholds is unparalleled. Therefore, modifying the whole tax structure of the entire country can reap some unpredicted impacts; many of them can be negative also. So a number of academicians as well as administrators have shown their concerns about the implications of GST. Many of them have criticised the very nature of Indian GST having more than one GST rates while others have questioned the feasibility of proper implementation. The following contents in this section deal with the criticisms and challenges that have been deliberated with respect to GST.

\subsection{The dual GST system}

India has adopted a dual GST system which means the taxes will be levied by both Centre (CGST) and State (SGST). This means there would be 38 different tax statutes as the GST system will be administered by one federal GST, 29 state GSTs, 7 Union Territory GSTs and one Integrated GST. Though one may always argue that the current GST system is definitely simpler than the previous tax structure, having 38 tax statures is still a great challenge for the tax administration. Eminent scholar and senior tax lawyer Arvind Datar has criticised GST backed by the logic that Article 246 (A) states that, parliament and States can levy taxes on the supply of goods and services. In other words each state can levy its own taxes. As per the Supreme Court of India, States aren't the appendages of the Parliament and on $11^{\text {th }}$ of December, 2016, the nine judge bench of the entry tax case provided the verdict that "Every State is as sovereign as Parliament in its power to levy taxes". This means there is no barrier for any state Government to quit GST and decide its own path. The consequences of such an event can distort the entire GST system.

\subsection{Different tax rates}

Most of the developed countries have adopted a GST system with a single tax rate. However, in case of India there are almost 7 tax rates excluding cess that have been imposed under GST. The major classifications of tax rates include 5\%,12\%,18\% and $28 \%$. Added to that there are tax rates of $0.25 \%$ and $3 \%$ imposed on rough diamond and gold respectively. There are also an array of goods like fresh meat, fish, chicken, eggs, unpacked milk, butter milk etc. that have been exempted from GST i.e. 0\%. Also, there are additional taxes on sin goods over and above $28 \%$ of GST and many goods like 
petroleum products, alcohol, electricity, etc. All this have contributed in making the GST system complex and challenged the idea of a simple tax structure.

\subsection{Illogical allocation of GST rates}

The GST council has used imposition of variable GST on different goods and services rates depending on their merits and classifications namely essential, nonessential, and luxury goods. However, in cases of few goods the respective allocations of tax rates are hard to rationalise. One of such goods is sanitary napkins. Menstrual cycle is natural and hence sanitary napkin needs to be kept as an essential good. However, under GST, sanitary napkins have been imposed a GST rate of $12 \%$ (Ministry Of Finance, Government of India, 2017). Similarly, human hair and wastes of human hair attracts 0\% of GST while any goods used for cleaning the hair like shampoos and moisturisers have been imposed a GST rate of $28 \%$. It is hard to understand that in what way human hair and wastes of human hair are essential but shampoos that are used almost regularly for cleaning the hair is a luxury product. Another ambiguous example of such odd rate is the price of toothpastes, soaps and detergents. Given the logic that these products are almost used in every household on daily basis and the Narendra Modi led Government has been stressing on 'Swach Bharat' campaign, these products should have been kept under essential goods. However, to the surprise of many, toothpastes and soaps are levied a tax rate of $18 \%$ whereas detergents are taxed at $28 \%$ under GST. Further, India has been suffering a lot to push literacy rates upward and taxing stationary items like notebooks, registers, and paper boards with $12 \%$ or $18 \%$ may not sound logical to many (Raj, 2017).

\subsection{Confusions in implementation mechanism}

Though GST has been announced as a move that will simplify the tax structure in India, it involves few numbers of technicalities that may create confusions in its implementation process. An article in the Economic Times by Sharma (2017) highlights that there are still confusions among the traders, businessmen and even tax officers (who are going to implement GST) with respect to the technicalities involved in filing tax returns, ITC, anti-profiteering mechanisms, various tax slabs etc. that could have possibly arisen because of lack in preparedness (Pantaik, 2017). Other critics believe that GST is proving to be a "procedural hazard" for the small traders providing goods and services (Venu, 2017).

\subsection{Tax unification versus federalism}

Many eminent scholars like Bagchi (2003, 2006), Rao (2009, 2011), Rao (2010) and recently Patnaik (2016) have questioned the system of unified tax system in which 
States nonetheless becomes mere tax collecting agents and have a very little control over deciding the tax rates. Patnaik, (2016) opines that GST is anti-constitutional as the very nature of the federalism system in India empowers States to take its own decisions as per its requirements. With GST, the powers with respect to tax will be centralised in the hands of the Centre and States may have to always bargain with the centre in case of any necessary modifications required. Also, States across India vary greatly from each other in their governance and functioning. So what is good for Kerala may not be good for Odisha. With GST, the States will lose grip over the tax revenue decisions and hence, they may not completely be in a position to decide what is good for them in a given period of time.

\subsection{Higher dependency on e-resources}

To make a move towards digitalisation and transparency, all the GST related affairs like filing of return, submitting taxes, and amendment of Bills will be done over internet resources. A close analysis of this system will reveal that the $10^{\text {th }}$ to $15^{\text {th }}$ of every month all the suppliers of goods and services will be uploading their invoices to the GSTN. The magnitude of such transactions will be huge and one may always be skeptical regarding the system's ability to cope up with such a high load. Further, in the world of hacking, the security of such volumes of data is another major concern and threat always looms over the GSTN (Variyar, 2017).

\subsection{Increasing operating cost}

It has been argued that small and medium supplier of goods and services are lacking the infrastructure to accommodate GST. For example, a medium scale retailer who was previously not having a computer could pay the tax manually at the respective tax offices. However, after implementation of GST, he/she has to either purchase a computer and data plan or go to the nearest internet cafes to file the taxes and returns. Adding to the misery is the fact that many of the suppliers who do not have any knowledge about the newly implemented GST may have to employ one chartered accountant temporarily to consult his/her business related affairs. These may cause a rise in the operating costs of the business.

\subsection{Multiple state registrations}

With the advent of GST, the registration of firms is PAN and State based. So, it has been made mandatory for all businesses to make separate registration for each state they operate in. Due to this, the number of filings at GSTN for the supplier has increased substantially. Furthermore, the any firm operating within only one state but having 
different business verticals have to register separately for each business vertical (Central Board of Excise and Customs, 2017). Multiple registrations may put an extra burden on the service providers who operate small shops in separate States.

\subsection{Problems with exemption limit}

Under GST, manufacturing units with an annual turnover of only 20 lakhs or less is considered to be an exempted category. This threshold limit earlier in the pre-GST period was 1.5 crores for manufacturing units. This comes as an extra burden on the small and medium scale enterprises that are competing against the already established businesses. The burden is not only in terms of taxes to be paid but also in terms of the formalities for GST registration and filing of return etc. On the other hand, due to the higher exemption limit given to the trading industries there are possibilities of mushrooming growth in the number of exempted category businesses operated by the one single family.

\subsection{Conclusion}

There is absolutely no doubt that the GST has been a huge tax reform in terms of the its massive impact and magnitude of its implementation. The results of it are to be seen over a long period of time. This paper focuses on the diverse voices raised for and against the implications of GST which appeared in the leading dailies, periodicals and other publications. On the one hand, nano technology and other facilitators of various purchases are simplifying the people-industry interface and on the other hand initiatives like GST are entangling the fundamental role obligations of duty bound citizens with lot of complexities. Yet, the long-term effects of GST would bring to fore the outcomes that will indicate whether the GST - mooted as 'One Nation, One Tax' is just a catchy phrase or driving force. In India, any declaration or implementation is imbued with several paradoxes. GST is also not far behind in the aspect which is calibrated in this work with the aid of cues drawn from various reports. The pricing methods are flawed at the first instance itself as lots of essential articles are being charged highly. The disparities in the billing systems too have spilled oil into the fire. This work provides insight on the beneficial impacts advocated by GST while highlighting the challenges. Constant monitoring and periodic evaluations can make things better in the long run. If the political will power and synergy between the Centre and States diminishes, GST shall ricochet to hit the economy badly. The foresight of financial advisors and economic experts only can save the day for the country. 
64 | VISION: Journal of Indian Taxation, Volume 4, Issue 1, January-June 2017

\section{References}

Bagchi, A. (2003). Rethinking federalism: Changing power relations between the Center and the states. Publius: The Journal of Federalism, 33(4), 21-42.

Bagchi, A. (2006). Towards GST: Choices and trade-offs. Economic and Political Weekly, 41(14), 1314-1317.

Bardopoulos, A. (2015). E-commerce and the effects of technology on taxation.Switzerland: Springer International Publishing.

Behrens, K, Hamilton, J, Ottaviano, G, \& Thisse, J. (2004). Destination versus origin-based commodity taxation and the location of industry. C.E.P.R. Discussion Papers, London, UK:. Retrieved from https://ideas.repec.org/p/cpr/ceprdp/ 4671.html

Central Board of Excise and Customs.(2017). GST Registration. Ministry of Finance, Government of India. Retrieved from http://www.cbec.gov.in/resources//htdocscbec/gst/regn-GST-onlineversion-07june2017.pdf;jsessionid =07259C8E3B40C184F1D 438F3D4EEE9D8

Datar, A., \& Vaitheeswaran, K. (2015, September 19). GST's seven deadly defects. The Indian Express. Retrieved from http://indianexpress.com/article/opinion/columns/gstsseven-deadly-defects/

Dhanorkar, S. (2017, May 29). GST likely to reduce inflation: Siddhartha Bothra, Motilal Oswal AMC. The Economic Times. Retrieved from http://economictimes. indiatimes.com/wealth/personal-finance-news/gst-likely-to-reduce-inflation-siddharthabothra-motilal-oswal-amc/articleshow/58868838.cms

Ecker, T. (2013). A VAT/GST model convention. Amsterdam: International Bureau of Fiscal Documentation (IBFD).

ET Bureau. (2016, August 4). GST: Long-drawn agenda put by Manmohan Govt. The Economic Times. Retrieved from http://economictimes.indiatimes.com /news/politics-and-nation/gst-long-drawn-agenda-put-by-manmohangovt/articleshow/53533195.cms 
GST Council of India. (2017a). GST: Concept and status-as on 01st May, 2017. Retrieved from http://www.gstcouncil.gov.in/sites/default/files/gst-knowledge/GSTconcept-status-ason01052017.pdf

GST Council of India. (2017b). GST-FAQs. Retrieved from http://gstcouncil.gov.in/sites /default/files/faq/FAQs\%20Website\%2007\%20July.pdf

Gupta, M. (2017, June 29). GST: A 17-year-old dream, 17 phases towards creating history. Indiatoday.In. Retrieved from http://indiatoday.intoday.in/story/gst-history-arunjaitley-tax-reform-july-1/1/990641.html

Jha, D. (2017, June 5). GST: Jewellers breathe easy with 3\% tax on gold, 0.25\% on rough diamond. Business Standard. Retrieved from http://www.businessstandard.com/article/economy-policy/gst-jewellers-breathe-easy-with-3-tax-on-gold-025-on-rough-diamond-117060300892_1.html

Lourdunathan, F. \& Xavier, P. (2017). A study on implementation of goods and services tax (GST) in India: Prospects and challenges. International Journal of Applied Research, 3(1), 626-629.

Ministry of Finance, Government of India. (2016). Frequently Asked Questions (FAQs) on Goods and Services Tax (GST). Retrieved from http://pib.nic.in/newsite/ PrintRelease.aspx? relid $=148240$

Ministry of Finance, Government of India. (2017). Cabinet approves four GST Bills. Retrieved from http://pib.nic.in/newsite/PrintRelease.aspx?relid=159523

Mukhopadhyay, S., \& Poddar, S. (2009, July 1). Is a unified GST better than a dual one?. Business Standard. Retrieved fromhttp://www.business-standard.com /article/opinion/-39-is-a-unified-gst-better-than-a-dual-one-39-109070100038_1.html

Narasimhan, T. (2016, June 15). Why is Tamil Nadu objecting to GST?. Business Standard. Retrieved from http://www.business-standard.com/article/economy-policy /why-tamil-nadu-objects-current-gst-116061401004_1.html 
Pantaik, S. (2017, July 3). GST: Confusion marks enforcement. The Hindu. Retrieved from http://www.thehindu.com/news/cities/Visakhapatnam/gst-confusion-marksenforcement/article19199902.ece

Patnaik, P. (2016, June 28). A blow against federalism. The Telegraph. Retrieved from https://www.telegraphindia.com/1160628/jsp/opinion/story_93525.jsp

Keshap, P. K. (2015). GST - Goods and services tax in India. Journal of Global Economics, 3, 159.doi:10.4172/2375-4389.1000159

Purohit, M. C. (1993). Adoption of value added tax in India: Problems and prospects. Economic and Political Weekly, 28(10), 393-404.

Raj, S. (2017, July 4). Odd tax rates within GST: Human hair exempt from tax; shampoos attract 28\%. Money Control. Retrieved from http://www.moneycontrol. com/news/business/economy/odd-tax-rates-within-gst-human-hair-exempt-from-taxshampoos-attract-28-2318057.html

Rao, M. G. (2009). Goods and services tax: Some progress towards clarity. Economic and Political Weekly, 44(51), 8-11.

Rao, M. G. (2011). Goods and services tax: A gorilla, chimpanzee or a genus like'primates'? Economic and Political Weekly, 46(7), 43-48.

Rao, R. K. (2010). Goods and services tax: The 13th Finance Commission and the way forward. Economic and Political Weekly, 45(48), 71-77.

Schenk, A., \& Oldman, O. (2001). Value added tax. Ardsley, N.Y.: Transnational Publishers.

Sharma, S. (2017, June 29). Mega GST confusion: Here are five issues that need more clarity. The Economic Times. Retrieved from http://economictimes.indiatimes.com/news /economy/policy/mega-gst-confusion-here-are-five-issues-that-need-more-clarity/articles how /59371969.cms

Teltumbde, A. (2017). One Nation, One Market. Economic and Political Weekly, 47(47 \& 48), 10-11. 
Variyar, M. (2017, May, 30). GST rollout: GST Network seeing several cyber threats, taking strong steps to ward them off. The Economic Times. Retrieved from https://economictimes.indiatimes.com/tech/internet/gst-rollout-gst-network-seeing-sever al-cyber-threats-taking-strong-steps-to-ward-them-off/articleshow/58901543.cms

Vasanthagopal, R. (2011). GST in India: A big leap in the indirect taxation system. International Journal of Trade, Economics and Finance, 2(2), 144-146.

Venu, M. (2017, June 17). GST is proving to be a procedural nightmare for small service providers and traders. The Wire. Retrieved from https://thewire.in/148289/gstimplementation-small-traders/ 